\title{
ASTRONOMICAL INTERPRETATION OF EARLY PRAYER TIMES (Study of Differences in Determination of Early Prayer Times From The Text and Astronomical Prespective)
}

\author{
Muhammad Rifqi Hasan
}

Al-Ishlah Islamic Boarding School, Mangkang

ripequi@gmail.com

\section{Abstract}

Theoretically the prayer times have been determined by the Koran and Sunnah through the phenomenon of the movement of the sun. Based on the instructions of the Koran and the Sunnah there are various nashes that seem to contradict one another. For example, in the determination of early Fajr time, nashexpresses with some terminologhy, for example, ghalas, isfar, and ishbah. This needs to be defined practically in astronomical rules, making it easier for us to carry out worship. This paper will describe the meaning of prayer times from the language of the Koran and Sunnah into astronomical rules, so that prayer times can be easily reckoned and determined, without having to change the phenomenon of the sun every time it will perform prayers. This paper will include the debate of scholars in interpreting sharia in astronomical rules, so that this paper is not only doctrinal, but invites us to think more creatively in determining prayer times.

Keyword : Astronomical Interpretation, Early Prayet Times, Text and Astronomical

Prespective

\section{Abstrak}

Secara teoritis waktu salat telah ditentukan al-Quran dan Sunnah melalui fenomena pergerakan matahari. Berdasarkan petunjuk al-Quran dan Sunnah terdapat beragamnas yang seolah-olah bertentangan satu dan lainnya. Misalnya, dalam penentuan awal waktu Subuh, nas mengungkapkan dengan beberapa lafal misalnya, ghalas, isfar, dan ishbah. Ini perlu didefinisikan secara praktis dalam kaidah astronomi, sehingga memudahkan kita dalam pelaksanaan ibadah. Tulisan ini akan mendeskripsikan pemaknaan waktu shalat dari bahasa al-Quran dan Sunnah ke dalam kaidah-kaidah astronomi, sehingga waktu shalat dapat dengan mudah dihisab dan ditentukan, tanpa harus merukyah fenomena matahari setiap akan melaksanakan shalat. Tulisan ini akan menyertakan perdebatan ulama dalam memaknai bahasa syar'i dalam kaidah astronomi, sehingga tulisan ini tidak hanya 
bersifat doktrin, namun mengajak kita untuk berfikir lebih kreatif dalam menentukan waktu shalat.

Kata Kunci : Interpretasi Astronomi, Awal Waktu Shalat, Prespektif Teks dan Astronomi

\section{A. Introduction}

In general, worship is basically divided into two, namely worship that is general in nature and worship that is specific in nature. In general worship (mu'amalah issues) the basic rule is "permissible - ibahah" which is basically as long as everything is allowed until there is prohibition. In other words that in this context, worship is all the goodness that is done and allowed by syara '. In contrast to the issue of special worship, it is tied to a principle of "iitiba'u Rasul" which is carried out by following the example of the Prophet. And according to the rules of fiqh it is said that in special prayers, basically it is prohibited unless there is an order. not practiced by the Prophet, it is considered a heretical practice which is forbidden.

Science that is very important for Muslims is the science of astronomy ${ }^{1}$, because it is related to the implementation of worship, including; prayer, fasting and pilgrimage. In connection with the prayer service, because of the importance of this worship, the Holy Prophet Muahammad SAW immediately received the order regarding the obligation to pray without the intermediary of revelation, which was different from other orders of worship. The appointment of the order is still general in nature, in other words, the time and method has not been determined. Therefore, through the Prophet's explanation, the times and methods of the prayers were made clearer.

At the time of the Holy Prophet Muhammad SAW, determining the timing of prayer was associated with astronomical phenomena at that time (especially the position of the sun), this is understood from the explanation of the hadith from Abdullah bin Amar narrated by Imam Muslim, that when the Archangel Jibril met the Prophet Muahmmad SAW and taught the times of prayer, The prayer times are determined based on the movement of the sun. Zuhr prayer starts from the time the sun moves away from the meridian (post meridiem) until the shadow of something is the same length,

${ }^{1}$ Ukurannya dan segala sesuatu yang berhubungan dengannya. Depag: Badan Hisab dan Rukyat, Almanak Hisab Rukyat (Jakarta: Proyek Pembinaan Badan Peradilan Agama Islam, 1981), h. 14. 
the Asr prayer starts when the shadow of something is the same length or since the shadow of something is twice its length until the sun turns yellow, Maghrib prayer starts from sunset until the disappearance of red mega, Isha prayer starting from the disappearance of the red mega until midnight, and Fajr prayers starting from dawn as long as the sun has not risen².

The following is a hadith from Dàr Ihya at-Turats al-'Arabi, 1415/1995 by Imam Muslim in Shahì Muslim Syarah an-Nawawì, Juz II, III:

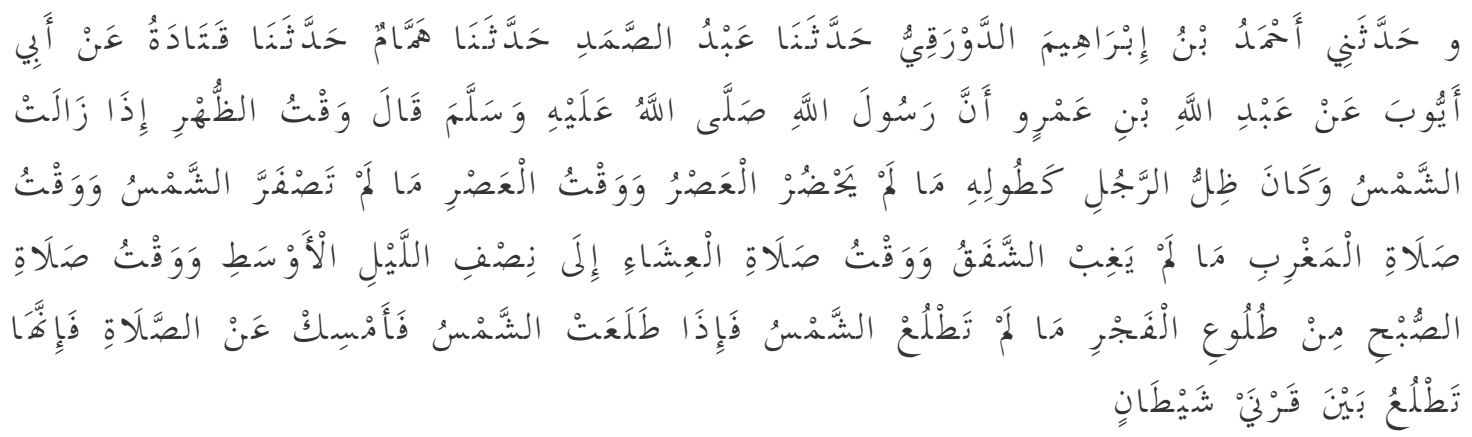

The development of science and technology has contributed to determining prayer times. The initial determination of prayer times above can be calculated astronomically, without looking at the phenomenon of the sun's movement anymore. This means that Muslims no longer perform prayers with the effort of seeing the sun slipping, seeing the length of the shadow of an object, seeing the sunrise and setting, or seeing the disappearance of the red mega, but can immediately see the prayer time based on the results of the reckoning. The prayer times which have been the reference for Indonesian Muslims, apart from being based on syar'i guidelines, are also linked to the position of the sun on the celestial pole ${ }^{3}$. That is, in determining the time of prayer, the position of the sun has been taken into account, especially the height, the zenith distance, the early dawn phenomenon, the sunrise, the sun crossing the meridian, the

${ }^{2}$ Imam Muslim, Shahì Muslim Syarah an-Nawawì, Juz II,III (Beirut: Dàr Ihya at-Turats al-'Arabi, 1415/1995), h. 95

${ }^{3}$ Bola Langit/al-kurrah asy-Syamàwiya /celestial globe, dalam realitas empirik tidak ada, hanya karena ruangan cakrawala ini sangat luas, maka para sarjana menganggap bola langit itu ada, sekedar untuk memudahkan penyelidikan di angkasa raya. Adapun bola langit yang dimaksud adalah ruangan yang sangat luas yang berbentuk bola yang dapat dilihat sehari-hari, tempat matahari, bulan, dan bintang-bintang bergeser setiap saat. Sebagaimana terdapat dalam Susiknan Azhari, Ensiklopedi Hisab Rukyat (Yogyakarta: Pustaka Pelajar, 2008), h. 46 
sunset, and the late dusk phenomenon. This effort was taken, with the aim of making it easier for Muslims to perform their prayers ${ }^{4}$.

So far, so far, there are not many complicated problems in determining prayer times. However, recently it has become a hot topic of conversation among Muslims (Indonesia). This polemic arises because of the various interpretations of the hadith texts relating to prayer times, which are then linked to the astronomical phenomenon of the position of the sun at the beginning of the prayer time. One example of a problem published in Qiblati Magazine is that the dawn of time used in Indonesia has not arrived yet (24 minutes too fast). Based on the above background, this paper describes the "Interpretation of Prayer Times from the Language of the Al-Quran and Sunnah into Astronomical Rule".

\section{B. Method}

This research is a type of literature research whose purpose is to determine the interpretation of prayer times from the Al-Quran language and the Sunnah into astronomical principles. The interpretation of the language of the Koran in this study was obtained from Imam Muslim, Shahì Muslim Syarah an-Nawawì, Juz II, III (Beirut: Dàr Ihya at-Turats al-Arabi, 1415/1995). While the astronomical rules, researchers are based on the Hisab and Rukyat Agency, Almanac Hisab Rukyat, Ministry of Religion of the Republic of Indonesia.

\section{Discuss and Result}

\section{C.1. Determine the Beginning of Prayer Times}

Based on the instructions of the Qur'an and the sunnah of the Prophet Muhammad SAW, it can be understood that the provisions of prayer times are related to the position of the sun on the celestial sphere. So in a scientific perspective (astronomy) for determining the initial time of prayer there are several important things to understand earlier, including: the position of the sun, especially the sun's height $(\mathrm{h})$, the zenith distance (bu'du as-sumti), $\mathrm{Zm}=900-\mathrm{h}$. The phenomena of early dawn

\footnotetext{
${ }^{4}$ Zenit (Samt ar-Ras) adalah titik puncak (titik tertinggi) pada bola langit, persis berada di atas kepala, sehingga setiap tempat atau orang akan memiliki titik zenit masing-masing sesuai keberadaannya.
} 
(morning twislight), sunrise, sun crossing the meridian (culmination), sunset (sunset) and late twilight (evening twilight) are related to the zenith distance of the sun ${ }^{5}$.

Instructions of the traditions of the Prophet Muhammad regarding prayer times. In general, there are two traditions which explain the prayer times for the five obligatory prayers. The hadith referred to is as follows. First; from

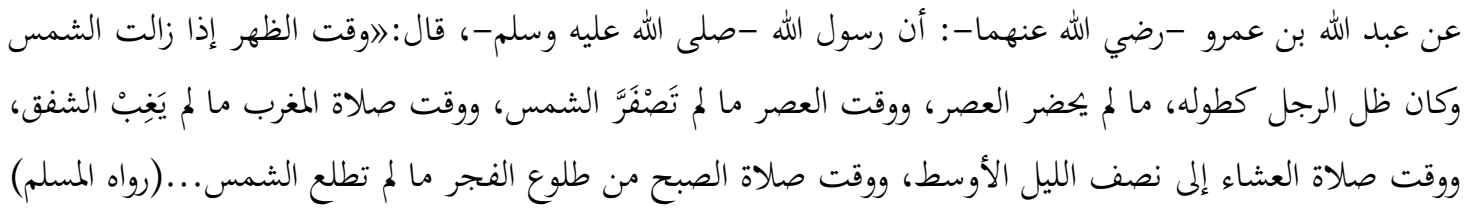

"That the Messenger of Allah (Muhammad SAW) had said;" Duhur time is what if the sun has slipped until the shadow of a person is the same length as his body, namely before the time of Asr. The red has not disappeared, the time of Isha prayer until the second midnight, while the time of Fajr prayer starts at dawn until the sun rises ... "(Narrated by Muslim) ${ }^{6}$

The beginning of the prayer time is determined by the position of the sun 5 seen from a certain place on earth. Zuhr time begins when the sun moves away from the meridian, Asar time begins when the shadow of an object is as long as the object or twice the length of the object. Maghrib time since sunset, Isha time since the disappearance of syafaq, and Fajr time since dawn eadidiq or at the time of ghalas. In other words, the position of the sun provides the phenomenon of determining the timing of prayers.

The results of observations by astronomers and islam astronomers, concluded that the pseudo-journey of the sun is relatively constant. So, when the sun rises, sets, slips and forms shadows can be taken into account. It is said that the pseudo-journey of the sun, because the daily journey of the sun that rises from the East and sets in the West, is not the actual motion of the sun, but is caused by the earth's rotation on its axis (rotation) during a day and night ${ }^{7}$. With the astronomical basis above, the time of prayer

\footnotetext{
${ }^{5}$ Encep Abdul Rojak, Amrullah Hayatudin, and Muhammad Yunus, 'SALAT : Analisis Jadwal Waktu Salat Kota Bandung', Al-Ahkam, 27.2 (2017), 241-66.

${ }^{6}$ Imam Muslim, Shahih Muslim bi Syarhan Nawawi, (Kairo : Dar al-Fikr, 1981), Juz V, p. 112.

${ }^{7}$ Merujuk pada teori Copernicus (matahari sebagai pusat tata surya), terdapat dua peredaran bumi yaitu rotasi dan revolusi. Rotasi bumi adalah peredaran bumi pada porosnya dari arah Barat ke Timur, dengan satu kali putaran penuh $=360^{\circ}$ ditempuh selama sekitar $24 \mathrm{jam}$, akibat dari rotasi ini, terjadi perbedaan waktu dan pergantian siang malam di permukaan bumi. Dalam hal ini setiap 1 jam menempuh jarak $15^{\circ}$, setiap $1^{\circ}$ ditempuh selama 4 menit, setiap 1 menit waktu $=15$ menit busur, dan 1 menit busur $=15$ detik waktu.
} 
in relation to the position of the sun can easily be calculated. The following is an astronomical study of the position of the sun at the beginning of prayer time:

\section{Dzuhur Time}

The start of the Zuhr time is defined since the entire sun's circle leaves the meridian, usually taken to be about two degrees after midday. When it culminates above the sun's circular center is on the meridian. Or in other words, the sun's center point is separated from the local meridian whose height is relative to the sun's declination and latitude ${ }^{8}$.

When the sun shifts from the meridian, its center point also shifts. Likewise, if the sun shifts from the zenith point, its culmination automatically shifts too. And what causes the culmination point to shift is the latitude of the place and the declination of the sun so that the latitude of the place is considered to be the same price as the zenith distance and the center of the sun when it culminates after being reduced by the sun's declination.

The formula used at the culmination is; $=12$ - e., This formula is derived from $\mathrm{Zm}=(\mathrm{p}-\mathrm{d})$, because the sun's height $=900$, then $\mathrm{p}=\mathrm{d}$ too. Thus $\mathrm{hm}=900-(\mathrm{p}-$ d), because $\mathrm{Zm}$, p, and $\mathrm{d}$ the price is considered to be equal to 0 . From this process, the beginning of the noon prayer time which is understood from the hadith as "slipping the sun"9.

Sedangkan, revolusi bumi (gerak tahunan bumi) adalah peredaran bumi mengelilingi matahari dari arah Barat ke Timur, dengan satu kali putaran penuh $360^{\circ}$ memerlukan waktu 365,2425 hari. akibat dari revolusi ini, terjadi pergantian musim di permukaan bumi. Muhyiddin Khazin, Ilmu Falak dalam Teori dan Praktek (Yogyakarta: Buana Pustaka.: 2008), h. 29.

${ }^{8}$ Moelki Fahmi Ardliansyah, 'Implementasi Titik Koordinat Tengah Kabupaten Atau Kota Dalam $\begin{array}{llllll}\text { Perhitungan Jadwal Waktu Salat', Al-Ahkam, } 27.2 & \text { (2017), } 213\end{array}$ <https://doi.org/10.21580/ahkam.2017.27.2.1981>.

${ }^{9}$ Nursodik Nursodik, 'Kajian Kriteria Hisab Global Turki Dan Usulan Kriteria Baru MABIMS

$\begin{array}{llllll}\text { Dengan Menggunakan Algoritma Jean Meeus', Al-Ahkam, } 18.1 & \text { (2018), } 119\end{array}$ <https://doi.org/10.21580/ahkam.2018.18.1.2353>. 


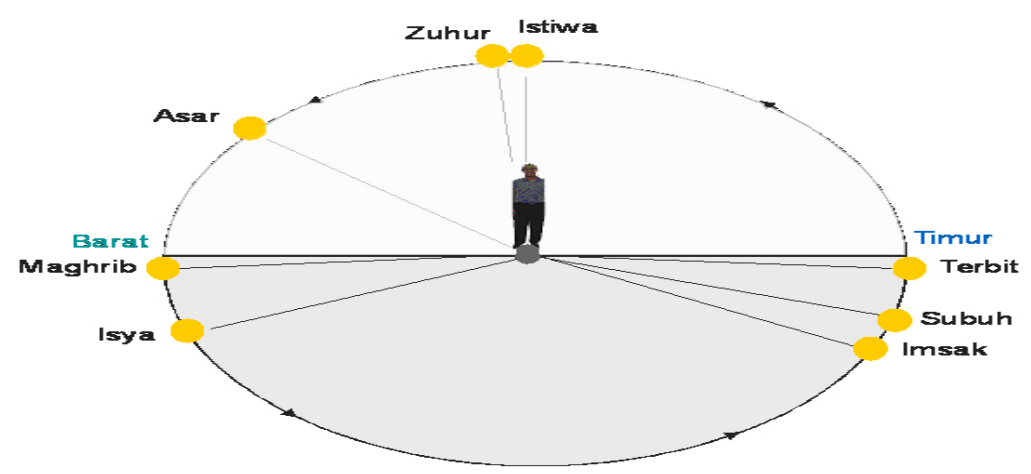

Pic. 1 The position of the sun at the start of the fardu prayer

The picture shows that when the sun slips, or shortly after the entire sun circle leaves its culmination point in its daily cycle, that is the beginning of Zuhr time. The number 12.00 is considered to be equal to 900 because the sun is at the zenith point, while e is the equation of time. To find out whether the timekeeping data in the nautical almanac is positive or negative, it is necessary to look at the Mer Pas. If the Mer Pass is more than 12.00 hours, it means the time aver is negative (-), and if the Mer Pass is less than 12.00 hours it means the time averager is marked positive $(+)$. Time smoothing data that determines when the sun "culminates" each day changes, but from year to year it is relatively the same ${ }^{10}$.

The explanation above shows that astronomically Zuhr time begins when the entire circle of the sun leaves the celestial meridian until the shadows are as long as the object or longer than the object. Astronomical phenomena like this (the length of the shadow of an object is longer than the object) can occur, when the sun culminates far from the Headquarters. Furthermore, the time of Zuhur is formulated with 12 - e.

\section{Ashar Time}

The beginning of the Asr prayer time in astronomy is stated as the height of the sun equal to the zenith distance of the sun's center at the culmination time plus the number one. According to the hadith guidance that the beginning of the Asr

${ }^{10}$ Almanak-almanak astronomis seperti the nautical almanac dan American Ephemeris selalu memuat saat matahari berkulminasi dalam data harian. Dalam the American Ephemeris saat matahari berkulminasi diistilahkan dengan Ephemeris transit. Datanya disediakan dalam satuan jam, menit dan detik sampai 2 angka dibelakang koma. Sementara itu dalam almanac nautika matahari berkulminasi diistilahkan Mer Pass mempergunakan satuan jam dan menit. Dalam almanac nautika juga disediakan data perata waktu (equation of time) untuk jam 00 dan jam 12.00 GMT dalam satuan menit dan detik lihat ibid., h. 73. 
prayer time is when the shadow of an object is the same length as the object, then this astronomical-reckoning can be achieved by the first determines the sun's height at Asr (ho) and the second determines the sun's time angle (to).

Referring to the hadith, the Holy Prophet performed the Asar prayer when the image of something was equal to its height or the image of something was twice its height. The astronomical picture is that when the sun crosses the meridian, a stick that is stuck perpendicular to a flat plane will form a shadow whose length is determined by the height of the sun when it culminates. The higher the sun's position, the shorter the stick's shadow, and the lower the sun's position, the longer the stick's shadow. Thus, the length of the shadow of an object standing upright on a flat plane (at the beginning of Asar time) is not fixed, because it depends on the position of the sun. ${ }^{11}$.

Astronomically, the height of the sun at the beginning of Asar time calculated from the horizon along the vertical circle is: $\operatorname{cotg}$ ha $=\operatorname{tg}(z \mathrm{~m}+1)$ or the length of the image of Asar time $=$ the image of the Zuhur time + one time the object's shadow. In this case it depends on the position of the sun when it culminates, if when the culmination does not form a shadow, then astronomically during Asar time, the image of an object that stands perpendicular to the surface of a flat plane will be equal to the height of the object. If when the culmination has formed a shadow, then it is possible that the shadow will be higher than the object ${ }^{12}$.

In connection with the above, Susiknan Azhari stated that the time of Asar began when the length of the shadow of an object was the same as the object plus the length of the shadow when the sun culminated until evening time. This opinion is based on Jabir's hadith (the first day Jibril taught prayer times) However, Azhari added to the length of the shadows when the sun culminates, so that when the sun is culminating, for example the length of the shadows is an inch, then the beginning

${ }^{11}$ Wildani Hefni, 'Dīnāmikiyyah Jam’iyyah Nahḍah Al-“Ulamā” Fī Ithbāt Awā’il Al-Shuhūr AlQamariyyah Bi Indunisiyā', Al-Ahkam, 28.2 (2018), 263-86.

${ }^{12}$ Cut Rahma Rizky and others, 'Hukum Islam Dan Patronase Dalam Penentuan 1 Ramadhan Di Bungong Keumang Pendahuluan Harian Rakyat Aceh Di Tahun 2017 Memberitakan Bahwa Ribuan MasyaRakat Kabupaten Nagan Raya , Mulai Melaksanakan Ibadah Puasa Ramadhan 1438 Hijriah . Ketetapan Berpuasa I', Al-Ahkam, 28.2 (2018), 193-218. 
of Asar time is when the shadows are equal to the height of the object plus an inch $^{13}$.

Based on the explanation above, it is concluded that astronomically, the height of the sun at the beginning of Asar time calculated from the horizon along the vertical circle is: $\operatorname{cotg}$ ha $=\operatorname{tg}(z \mathrm{~m}+1)$ or the length of the image of Asar time $=$ the image of the Zuhur time + one time the shadow of the object.

\section{Magrib Time}

The time of Maghrib prayer means when the sun sets (ghurub), that is, the entire disk of the sun is invisible to the observer. The solar disc has a diameter of 32 'arc minutes, half of which means 16 arc minutes, besides that near the horizon there is a refraction (incisar al-jawwi) which causes the sun's position to be higher than the actual fact assumed to be 34 arc minutes. Semidiameter correction (nishfu al-quthr) of the sun disk and refraction of the zenith distance of the sun at sunrise or sunset is 50 arc minutes.

Thus rising and setting scientifically defined when the zenith distance of the sun reaches $\mathrm{Zm}=90050$ '. The definition is for a place at an altitude at sea level or the zenith distance of the sun $\mathrm{Zm}=910$ when entering a correction for the low horizon due to the height of the observer's position $30 \mathrm{~m}$ above sea level. For the determination of the sunset time, usually 2 minutes are added when the sun sets because there is a prohibition on praying right at sunrise, sunset and the top.

For reckoning the determination of the beginning of Maghrib, the required data include; latitude, longitude, longitude, declination, time alignment and sun height $(\mathrm{h}=-1)$. In addition to these data, longitude corrections were also carried out, data on the results of the sun's culmination (zuhur formula) and ihtiyat. Based on the hadith, the time of Maghrib starts from sunset (gurùb) until the disappearance of the red mega (shafaq). Astronomically, what is meant by setting is when the entire disc of the sun is invisible to the observer, meaning that the solar disk is completely under the horizon. Thomas Djamaludddin stated:

${ }^{13}$ Thomas Djamaluddin., Menggagas Fiqh Astronomi (Bandung: Kaki Langit, 2005), h. 138. 
"Astronomically, sunrise or sunset is defined when the zenith distance is $z=90^{\circ} 50$ '(the Astronomical almanac) or $z=91^{\circ}$ if you include the correction for lower horizon due to the observer's height of 30 meters from the ground. For the determination of the time for Maghrib prayer, usually 2 minutes are added when the sun sets because there is a prohibition on praying right at sunrise, sunset, or the top 114.

According to Abdur Rachim, the sun was setting, when the sun disk was completely under the horizon, and at that time the horizon coincided with the edge of the upper sun disk. The distance from the horizon to the center of the sun is $1 / 2$ the sun's diameter, while the sun's diameter is 32 'on average. Thus, the distance from the sun's center from the horizon is $1 / 2 \times 32^{\prime}=16^{\prime}$. In addition to the $16^{\prime}$ (semidiameter) correction, it is necessary to take into account the refraction (refraction of light) at sunset, the average is 35', meaning that actually the sun has set earlier if there is no refraction. ${ }^{15}$.

Based on the results of research visually and astronomically, the Department of Religion formulated the zenith distance of the sun at sunset to be $90^{\circ}+\left(34^{\prime}+16^{\prime}\right.$ +10 ') for places on the beach, so that the position of the sun at that time has a zenith distance of $91^{\circ}$ or $-1^{\circ}$. Meanwhile, for other places it should be adjusted to the height of the place and its effect on the low horizon which is usually used the formula: $D^{\prime}=1.76 \times \sqrt{ }$ the height of the place. Referring to the explanation above, astronomically Maghrib time starts when the solar disk is completely under the horizon (the sun has set). The position of the sun at that time had a distance of $91^{\circ}$ or $1^{\circ}$ below the horizon.

4. Isya' Time

Astronomically, the beginning of the Isha prayer time is marked by the waning of red light (ash-syafaq al-ahmar) in the western part of the sky, which is a sign of the entry of dark night. The substance of this information can be seen in the Koran in surah al-Isra 'verse 78. In astronomy, this event is known as the end of astronomical twilight (astronomical twilight). The height of the sun at that time was

\footnotetext{
${ }^{14}$ Thomas Djamaluddin., Menggagas Fiqh Astronomi (Bandung: Kaki Langit, 2005), h. 139.

${ }^{15}$ Abdur Rachim, Ilmu Falak (Yogyakarta: Liberty, 1983), h. 23-24.
} 
$18^{\circ}$ below the horizon (horizon ), the west and the zenith distance of the sun is 108 ${ }^{\circ}\left(90^{\circ}+18^{\circ}\right)$, or $\mathrm{h}=-18^{\circ}$.

In astronomy it is known as astronomical twilight. According to Abdur Rachim, twilight is divided into three levels: First; cipil twilight, which is when the sun is $6^{\circ}$ below the horizon. At that time objects in the open field had visible boundaries and the brightest stars could be seen. Second; nautical twilight, which is when the sun's position is $12^{\circ}$ below the horizon, if we are at sea, the horizon is almost invisible and all bright stars can be seen. Third; astronomical twilight, which is when the sun's position is $18^{\circ}$ below the horizon, at that time it is completely dark at night, which marks the beginning of Isha ${ }^{16}$.

According to W.M. Smart when the sun is $18^{\circ}$ below the horizon (zenith distance $108^{\circ}$ ), the sunlight is no longer visible. According to him, the interval between sunset time and when the sun is $108^{\circ}$ zenite is called duration of evening twilight $^{17}$. The Department of Religion formulates the position of the sun at the beginning of Isha time by way of observation at dusk. These observations are made by seeing empirically when red light is lost in the western sky, or by astronomical understanding when the stars in the sky reach their maximum light. The observations show that at that time the sun's zenith distance $=108^{\circ}$, in other words, the sun's height at that time averaged $=-18^{\circ}$.

According to Saadoe'ddin Djambek, the entry of Isha time was marked by the loss of syafaq or the red color in the western sky. This situation occurs when the

\footnotetext{
${ }^{16}$ Ahmad Fauzi, 'Almanak Menara Kudus : Study of Hisāb Results in 1990 until 2019 Introduction Period. The Form of the Almanac Is Quite a Lot, Even in Calculations It Has Its Own In Indonesia There Is a Famous Almanac, Almanak Menara Kudus Which Is a Monumental Work of an Ulama Named KH . Turaichan ( Yi Tur ). He Was a Wise Man Whose Expertise in Science Was Undoubtedly by Indonesian Astronomy Experts. Once, the Work Was One of the References in Determining the Beginning the Determination and Conviction of the Results of His Calculations of Any Determination and Anyone . One of Them Is Boldly Declaring That the Qibla Direction of the Al-Aqsha Mosque of Menara Kudus Must Be Straightened Because It Faces Too Far South. Though This Mosque Was Founded by One of Walisongo 's Sunan Kudus. This Is One Example of His Determination to Uphold KH . Turaichan Passed Away on 20 Th August 1999 in the Age of 84 . 4 Then His Expertise Was Continued by His Son Named Sirril Wafa Who Was the Successor in the Field of Astronomy Science and Currently Holds the Authority in the Making of Almanak Menara Kudus . Almanak Menara Kudus Is an Almanac That Uses the Circulation of the Moon ( Qamariyah ) or Lunar System and Includes Almanac Hijri ( Islamic ). According to Sirril Wafa, Almanak Menara Kudus Was Composed by KH . Turaichan', 29.1 (2019), 109-34.

${ }^{17}$ W.M. Smart, Textbook on Spherical Astronomy (Cambridge: University Press, 1977), h. 51
} 
sun's center point is located a few degrees below the horizon. Similar to the onset of dawn, this number is determined somewhat differently by reckoning experts, some specifying $16^{\circ}$, some $17^{\circ}$, some $18^{\circ}$. Saadoe'ddin Djambek himself holds an opinion $18^{\circ}$ below the horizon ${ }^{18}$.

The astronomical reason for taking the sun's position $18^{\circ}$ below the horizon, is because when the sun is in that position, the entire surface of the earth darkens. Due to the dark surface of the earth, objects in the open field could no longer be seen and the stars in the sky began to appear. Thus, it can be understood that the beginning of Isha time begins when the sun is $-18^{\circ}$.

\section{Subuh Time}

The beginning of the Fajr prayer is understood from dawn to when the sun will rise. Shadik dawn in astronomy is understood as the beginning of astronomical twilight (astronomical dawn), this light begins to appear in the eastern horizon before sunrise when the sun is at a position about $18^{\circ}$ below the horizon or a $108^{\circ}$ sun zenith distance. Another opinion says that the dawn of fingerprint begins when the sun is 20 degrees below the horizon or the zenith of the sun is 110 degrees, there is even an opinion of 15 degrees. In terms of reckoning the time of the dawn prayer, the data required is basically the same as the other compulsory prayer times, it's just that the end of the dawn prayer time needs to be known, that is, the sun is in a position of -1 degree $(h=-10)$ below the horizon .

Referring to the provisions of the hadith, the beginning of Fajr time starts from dawn and the hadith also states that dawn is divided into dawn kdzib and shàdiq. Of course, to understand this, it is necessary to know the astronomical criteria related to the phenomenon of dawn in question. According to Thomas Djamaluddin:

"The dawn of kdzib is not a dawn in the general sense, which astronomically is called the light of the zodiac. Zodiac light is caused by the scattering of sunlight by the inter-planetary dust that is scattered in the ecliptic plane that appears in the sky across the zodiac (a series of constellations that the sun appears to travel through). Therefore the dawn of kdzib appears to be sticking upwards like a wolf's tail, whose direction is in the direction of the ecliptic. The dawn of kadzib appears before dawn

\footnotetext{
${ }^{18}$ Rizky and others.
} 
when the night was still dark. Meanwhile, dawn shaddiq is the scattering of sunlight by particles in the air that surrounds the earth. In the language of the Koran it is likened to the expression "light for you is a white thread from a black thread", namely the transition from dark night (black) to the appearance of light (white). In the language of black physics means no light is emitted, and white means that there is light emitted. Since the source of the light is from the sun and the scatter is air, the light of dawn crosses the horizon. It is a sign of the end of the night, before sunrise. The closer the sun is to the horizon, the brighter the dawn will be" ${ }^{19}$.

The information above shows that astronomically, what is meant by dawn and is a sign of the beginning of Fajr time is the light that spreads or crosses along the eastern horizon, and horizontally, it fills the eastern sky. The phenomenon of early Fajr time is almost the same as the phenomenon of early Isha '. The beginning of Isha's time is marked by stars in the sky, their light reaches its maximum point due to the disappearance of red light in the western sky, which indicates a change from light to dark. Meanwhile, the beginning of Fajr time, marked by the beginning of the receding stars in the sky, is caused by the influence of sunlight coming in the eastern sky, which indicates a change from dark to light. ${ }^{20}$.

In connection with the description above, it can be described that each country has differences in determining the position of the sun at the beginning of Fajr. This difference is due to the geographical conditions of each country. Indonesia, which is located in the equatorial region, has a higher atmospheric thickness compared to countries far from the equator. Therefore, Indonesia has determined the position of the sun at the beginning of Fajr time to be $18^{\circ}-20^{\circ}$ below horizon.

\section{C.2. Analysis of the Sun Position when Determining Prayer Times}

Determination of prayer schedules, the most important astronomical data is the position of the sun in the coordinates of the horizon, especially the altitude or zenith

19 Thomas Djamaluddin, Twilight Menurut Astronomi, Makalah disampaikan pada «Temu Kerja Evaluasi Hisab dan Rukyat Kementerian Agama», Semarang, 23-25 Februari 2010, h. 1.

${ }^{20}$ If the phenomenon of late twilight is divided into three levels; cipil twilight, nautical twilight, and astronomical twilight, the phenomenon of early dawn also consists of three levels, namely: astronomical dawn, which is defined as the end of the night, when the starlight begins to dim due to the emergence of scattering sunlight. Usually defined on the basis of a light curve, the position of the sun is around $-18^{\circ}$. Nautical dawn is the dawn that shows the horizon for sailors, the position of the sun is around $-12^{\circ}$. And the civil dawn is the dawn that begins to reveal objects around us, the position of the sun is around -6 . Thomas.Djamaluddin, Twilight ..., 2010, 2. 
distance. The phenomena that we are looking for in relation to the position of the sun are dawn (morning twilight), rising, crossing the meridians, setting, and evening twilight. In this case, astronomy plays a role in interpreting the phenomena mentioned in the religious arguments (Al-Qur'an and the hadith of the Prophet) into the position of the sun. Actually, the interpretation is not uniform, but because the public has agreed to accept astronomical data as a reference, the criteria are relatively easy to put together.

Al-Bukhary said: "The most valid hadith in the matter of prayer times is the hadith from the Prophet Jabir. And the Jabir Hadith in terms of time narrated by Athá ibn Abi Rabah, Amr ibn Dinnar, Az-Zubair is similar to the hadith of Wahab ibn Kaisan from Jabir from the Prophet Muhammad SAW. ${ }^{21}$

Astronomically, the dawn of shidiq is understood as the beginning of astronomical twilight, starting from the emergence of light on the eastern horizon before sunrise when the sun is approximately 18 degrees below the horizon (zenith distance $z=108 \mathrm{o})$. Saaduddin Djambek takes the opinion that fajar is shidiq if $z=110 \mathrm{o}$, which is also used by the Hisab and Ru'yat Bodies of the Ministry of Religion of the Republic of Indonesia. The dawn of the shidiq is caused by the scattering of sunlight in the upper atmosphere. This differs from what is called a kidzib dawn (pseudo) in astronomical terms called zodiac light which is caused by the scattering of sunlight by interplanetary dust. ${ }^{22}$

Dzhuhur time is from the time the sun leaves the meridians, usually about 2 minutes after noon. For practical purposes, it is sufficient to take the midday time between sunrise and sunset. In determining the timing of origin, there is no agreement because the phenomenon on which it is based is unclear. The basis stated in the hadith, the Prophet SAW was invited to pray asar by the angel Jibril when the length of the image was the same as the actual height of the object and the next day the Prophet was invited when the length of the image was twice the height of the actual object. Although

\footnotetext{
${ }^{21}$ Muhammad Hasbi ash Shiddieqy, Mutiara Hadits 3 Shalat, Semarang: PustakaRizki Putra, 2003, hlm. 147

22 Aziz, Akhmad Luthfi. 'Internalisasi Pemikiran KH. Muhammad Sholeh Darat Di Komunitas Pecintanya: Perspektif Sosiologi Pengetahuan’. Living Islam: Journal of Islamic Discourses 1, no. 2 (November 28, 2018). http://ejournal.uin-suka.ac.id/ushuluddin/li/article/view/1733
}

Al-Hilal: Journal of Islamic Astronomy, Vol. 2, No. 2, Tahun 2020 p-ISSN : 2775-1236 ; e-ISSN : 2775-2119 
from this postulate it can be concluded that the origin of the original time is since the image is equal to the actual height of the object, this raises several interpretations because such phenomena cannot be generalized because in winter it can be achieved during midday, maybe even never because the image is always longer than the staff.

Based on the previous explanation, it is known that the time of the fardu prayer has been specifically determined based on the shar'i guidance, which is then defined based on the astronomical phenomenon of the position of the sun at that time. Hadith information that the time of Zuhur begins when the sun slips. Astronomically, what is meant by slipping is the time after the sun has reached its culmination point in its daily cycle or when the sun's center point is detached from the local meridian. Thus, astronomical references in determining the beginning of Zuhur time do not contradict the hadith. It's just that based on the formula that has been built so far, namely 12-e needs to be reviewed, because 12-e is when the sun culminates. Meanwhile, in syar'i when the sun culminates it is forbidden to pray. Even if there is a 2 minute ihtiyàt, it can only be applied to the surrounding area. If it is used by Muslims in the West of the area, they may pray when the sun culminates. The solution to this problem is not only using a 2 minute ihtiyat, but a minimum of 4 minutes ihtiyat ${ }^{23}$.

Regarding the time of Asar, several hadiths show two options for the beginning of time. The two choices of time are: first, when the shadow of an object is the same length as the object; second, when the shadow of an object is twice the length of the object. Astronomically, the Department of Religion uses the formula for the height of the sun when Asar is cotg ha $=\operatorname{tg}(z m+1)$. That is, the length of the image in Asar time $=$ the image of the Zuhr time + the image of the object. If the hadith is issued when the sun is directly above Mecca, then the astronomical phenomenon of the shadow of an object will be the same length as the object, according to the first indication (the beginning of Asar time). However, if the hadith is issued when the sun is culminating away from Mecca or the sun is far to the South, then when the culmination has formed a shadow, then the second indication (the shadow of an object is twice the length of the object) will be achieved. Therefore, the Asar time formula above becomes cotg ha $=\operatorname{tg}$

${ }^{23}$ Jayusman. 'Pemikiran Ilmu Falak Kyai Noor Ahmad SS'. IAIN Walisongo Semarang, 2013 
$(z m+2)$, the length of the time image Asar $=$ the image of the Zuhur time + twice the shadow of the object ${ }^{24}$.

Furthermore, for the time of Maghrib, between the syar'i guidance and the astronomical basis is not contradictory, because the hadiths describe the time of Maghrib starting at sunset. Astronomically, what is called sunset is when the entire solar disk is under the horizon, which is then made several corrections (refraction, semidiameter, and low horizon), so that the prayers are not right at sunset. The time of Isha begins with the loss of shafaq, and is known astronomically as the end of astronomical twilight (Astronomical Twilight), when the sun is $18^{\circ}$ below the horizon. Astronomical criteria like this, can be used as a reference for the beginning of Isha's time.

Based on the hadith, Fajr time begins at dawn shadaq. In this case, astronomers disagree in determining the criteria for the position of the sun at the beginning of the Fajr time. With reference to the hadith which explains that the Prophet performed the Fajr prayer at the time of ghalas, which was then interpreted as the beginning of the dawn of shddiq because after that the day began to lighten (in contrast to the natural phenomena after dawn of kadzib, i.e. the day grew dark again) then, if it is linked to astronomical grounds, This dawn is called the dawn of astronomy, when the starlight begins to dim because of the scattering of sunlight. Usually defined based on the curve of light, and at that time the sun's position is around $-18^{\circ}$. The Ministry of Religious Affairs uses the criterion -20 .

Another astronomical reason (taking the criteria $18^{\circ}-20^{\circ}$ below the horizon as applied in Indonesia which is different from some other countries), is because Indonesia's atmosphere which is in the equatorial region is relatively thicker than high latitudes, for example, the thickness of the troposphere at high latitudes is about $10 \mathrm{~km}$, in the equatorial region is about $17 \mathrm{~km}$. In other words, because the atmosphere in Indonesia is thicker, to scatter the higher light the position of the sun is at the bottom, so it will obviously be different from countries that are far from the equator. If you take the position of the sun at $15^{\circ}$, in conditions like in Indonesia, it means that it is getting light. If this is the case, then Fajr prayer is relatively fine because there is a choice of

\footnotetext{
${ }^{24}$ Maryani. 'Studi Analisis Metode Penentuan Waktu Salat Dalam Kitab Ad-Durus Al-Falakiyyah Karya Ma'sum Bin Ali'. IAIN Walisongo Semarang, 2010
} 
time (as long as it is not carried out at sunrise), but for people who are going to fast, because early Fajr time is often used as a benchmark for starting his fast and he is still eating sahur, then his fast becomes canceled.

Globally, the Koran has determined prayer times for Muslims, which is then clarified through the Prophet's hadith. The prayer time is determined based on the phenomenon of the position of the sun. With this reference, then astronomical formulas are built for each of the initial prayer times. Zuhur time is formulated with 12 e. Asar Time; cotg ha $=\operatorname{tg}(z m+1)$. Maghrib time begins when the sun is $1^{\circ}$ below the horizon. Isha time begins when the sun is $18^{\circ}$ below the horizon, and Fajr time when the sun is $18^{\circ}-20^{\circ}$ below the horizon ${ }^{25}$.

Furthermore, there is a link between the basis of syar'i and astronomy regarding the determination of the start of prayer times. However, for the time of Zuhur and Asar, it is necessary to review it. For the time Zuhur the formula that was built (12-e) was not in accordance with the syar'i foundation. That is, 12-e is when the sun culminates. Meanwhile, when you culminate it is prohibited to pray. The solution, a minimum of four minutes of ihtiyat is required. The formula for the height of the sun in Asar is not only formulated with cotg ha $=\operatorname{tg}(z \mathrm{~m}+1)$. However, it is also formulated with cotg ha $=$ $\operatorname{tg}(z m+2)$, to match the syar'i instructions. Wallahu a'lam bi as-shawab.

\section{Conclusion}

As a conclusion from the two sub-problems of this paper are as follows: According to syara 'Dhuhr prayer time, is when the position of the sun slips, while the time of Asr prayer, if the shadow of an object is the same length as the object. While the time of Maghrib prayer, is when the sun has set until the magnificent red has not disappeared or as long as the majestic red still exists. As for the time of the Isha prayer, which starts when the magnificent red disappears until dawn, in another narration until midnight or half the night, and for the Fajr prayer time, it is when dawn rises.

Furthermore, according to science (astronomy), the determination of the initial reckoning of prayer times is very much influenced by several important things in the

\footnotetext{
${ }^{25}$ Masruroh. 'Studi Analisis Hisab Awal Bulan Kamariah Menurut KH. Muhammad Hasan Asy'ari Dalam Kitab Muntaha Nataij Al-Aqwal'. Institute Agama Islam Negeri Walisongo Semarang, 2011
} 
ordinate system, including the sun's declination and time alignment. ; The beginning of Zuhur time; formulated since the entire circumference of the sun leaves the meridian, usually taken at about 2 degrees after midday, when it culminates above the center of the sun's circularity at the meridian. The beginning of the Asr prayer time; in astronomy expressed as the height of the sun is equal to the zenith distance from the center of the sun at the culmination time plus the number one. While the time of Maghrib prayer; means that when the sun sets (ghurub), that is, the entire disk of the sun is invisible to the observer. The solar disk has a diameter of 32 'arc minutes, half of which means 16 arc minutes. Furthermore, the beginning of the Isha prayer time; marked by the waning of red light (ash-syafaq al-ahmar) in the western part of the sky, namely as a sign of the entry of dark night, the height of the sun at that time is $18^{\circ}$ below the horizon, the west and the zenith distance of the sun is $108^{\circ}\left(90^{\circ}+18^{\circ}\right)$, or $\mathrm{h}=-18^{\circ}$. As for the beginning of the Fajr prayer; understood from dawn until the time the sun will rise. Shadik dawn in astronomy is understood as the beginning of astronomical twilight (astronomical dawn), this light begins to appear in the eastern horizon before sunrise when the sun is at a position about 180 below the horizon or a $108^{\circ}$ sun zenith distance. Another opinion says that the dawn of fingerprint begins when the sun is 20 degrees below the horizon or the zenith of the sun is 110 degrees, there is even an opinion of 15 degrees.

The legal basis for determining the beginning of prayer time consists of 2 kinds of arguments. The first is the naqly argument which includes the verses of the Al-Quran and the hadith of the Prophet. The two aqly arguments which consist of fiqhiyyah principles and the development of astronomy in general, especially astronomy. Furthermore, according to science (astronomy), the determination of the initial reckoning of prayer times is strongly influenced by several important matters in the ordinate system, including the sun's declination and time alignment; The beginning of Zuhur time; formulated since the entire circumference of the sun leaves the meridian, usually taken about 2 degrees after midday, when it culminates above the center of the sun's circularity at the meridian. The beginning of the Asr prayer time; In astronomy it is stated that the height of the sun is equal to the zenith distance from the center of the sun at the time of its culmination plus the number one. While the time of Maghrib 
prayer; means that when the sun sets (ghurub), that is, the entire disk of the sun is invisible to the observer. The sun disk is 32 arc minutes in diameter, half of which means 16 arc minutes. Furthermore, the beginning of the Isha prayer time; marked by the waning of red light (ash-syafaq al-ahmar) in the western part of the sky which is a sign of the entry of dark night, the height of the sun at that time was $18^{\circ}$ below the horizon, the west and the zenith distance of the sun was $108^{\circ}\left(90^{\circ}+18^{\circ}\right)$, or $\mathrm{h}=-18^{\circ}$. As for the beginning of the Fajr prayer; understood from dawn until the time the sun will rise. Shadik dawn in astronomy is understood as the beginning of astronomical twilight (astronomical dawn), this light begins to appear in the eastern horizon before sunrise when the sun is at a position about 180 below the horizon or a sun zenith distance of $108^{\circ}$. Another opinion says that the dawn of fingerprint begins when the sun is 20 degrees below the horizon or the zenith of the sun is 110 degrees, there is even an opinion of 15 degrees.

\section{E. Bibliography}

Abdur Rachim, Ilmu Falak (Yogyakarta: Liberty, 1983

Ardliansyah, Moelki Fahmi, 'Implementasi Titik Koordinat Tengah Kabupaten Atau Kota Dalam Perhitungan Jadwal Waktu Salat', Al-Ahkam, 27.2 (2017), 213 <https://doi.org/10.21580/ahkam.2017.27.2.1981>

Aziz, Akhmad Luthfi. 'Internalisasi Pemikiran KH. Muhammad Sholeh Darat Di Komunitas Pecintanya: Perspektif Sosiologi Pengetahuan'. Living Islam: Journal of Islamic Discourses 1, no. 2 (November 28, 2018). http://ejournal.uinsuka.ac.id/ushuluddin/li/article/view/1733

Depag: Badan Hisab dan Rukyat, Almanak Hisab Rukyat (Jakarta: Proyek Pembinaan Badan Peradilan Agama Islam, 1981)

Fauzi, Ahmad, 'Almanak Menara Kudus: Study of Ḥisāb Results in 1990 until 2019 Introduction Period. 29.1 (2019), 109-34

Hefni, Wildani, 'Dīnāmikiyyah Jam'iyyah Nahụah Al-“Ulamā” Fī Ithbāt Awā'il Al-Shuhūr Al-Qamariyyah Bi Indunisiyā', Al-Ahkam, 28.2 (2018), 263-86

Imam Muslim, Shahih Muslim Syarah an-Nawawi, Juz II,III (Beirut: Dàr Ihya at-Turats al'Arabi, 1415/1995), h. 95 
Imam Muslim, Shahih Muslim bi Syarhan Nawawi, (Kairo : Dar al-Fikr, 1981), Juz V, p. 112. Jayusman. 'Pemikiran Ilmu Falak Kyai Noor Ahmad SS'. IAIN Walisongo Semarang, 2013

Maryani. 'Studi Analisis Metode Penentuan Waktu Salat Dalam Kitab Ad-Durus AlFalakiyyah Karya Ma'sum Bin Ali'. IAIN Walisongo Semarang, 2010

Masruroh. 'Studi Analisis Hisab Awal Bulan Kamariah Menurut KH. Muhammad Hasan Asy'ari Dalam Kitab Muntaha Nataij Al-Aqwal'. Institute Agama Islam Negeri Walisongo Semarang, 2011

Muhammad Hasbi ash Shiddieqy, Mutiara Hadits 3 Shalat, Semarang: Pustaka Rizki Putra, 2003, hlm. 147

Nursodik, Nursodik, 'Kajian Kriteria Hisab Global Turki Dan Usulan Kriteria Baru MABIMS Dengan Menggunakan Algoritma Jean Meeus', Al-Ahkam, 18.1 (2018), 119 <https://doi.org/10.21580/ahkam.2018.18.1.2353>

Rizky, Cut Rahma, Agus Nurhadi, Postgraduate University, Islamic State, and Banda Aceh, 'Islamic Law and Patronage in Determining 1 Ramadan in Bungong Keumang Introduction The Aceh People's Daily In 2017 Reported That Thousands of People of Nagan Raya District, Started to Carry Out Worship Fasting Ramadan 1438 Hijriah. Provisions on Fasting I ', Al-Ahkam, 28.2 (2018)

Rojak, Encep Abdul, Amrullah Hayatudin, and Muhammad Yunus, 'SALAT: Analisis Jadwal Waktu Salat Kota Bandung', Al-Ahkam, 27.2 (2017), 241-66

Thomas Djamaluddin, Twilight Menurut Astronomi, Paper presented at the «Ministry of Religion Hisab and Rukyat Evaluation Meeting», Semarang, 23-25 February 2010

Menggagas Fiqh Astronomi (Bandung: Kaki Langit, 2005)

W.M. Smart, Textbook on Spherical Astronomy (Cambridge: University Press, 1977)

Al-Hilal: Journal of Islamic Astronomy, Vol. 2, No. 2, Tahun 2020

p-ISSN : 2775-1236; e-ISSN : 2775-2119 